\title{
PENERAPAN TEORI PENAFSIRAN HUKUM OLEH HAKIM SEBAGAI UPAYA PERLINDUNGAN HUKUM TERHADAP NOTARIS (Studi Atas Putusan Hakim Terhadap Tindak Pidana Pemalsuan Akta Otentik)
}

\author{
Agus Priono \\ E-mail: agusprionoklt@gmail.com \\ Notaris Kabupaten Klaten \\ Fakultas Hukum Universitas Sebelas Maret Surakarta \\ Widodo T. Novianto \\ E-mail: novianto@consultant.com \\ I Gusti Ayu Ketut Rachmi Handayani \\ E-mail:ayu_igk@yahoo.com \\ Dosen Fakultas Hukum Universitas Sebelas Maret Surakarta
}

\begin{abstract}
This articles aimed at to analyze the application of the Theory of Legal Interpretation by judges as an attempt of legal protection against the notary, are study of the judge's Verdict against the crime of falsification of the authentic deed. The kind of research in this article is doctrinal, while seen from its shape including research evaluative sense and perspective. The analysis used logic deduction. Legal basis in the provision of criminal sanctions against notary can be taken but in addition to must meet formulation offense which is in law office notary and the book the act of criminal law. Judge in applying criminal sanctions against of criminal falsification an authentic deed rules must payment the following: (1) the what may be punishable and meet elements formulated in an act; (2) work of violates the laws or against the law; (3) a mistake, in the form of both were (dolus) and neglect (culpa). Recommendations are : 1) examination the allegation act punishable in forgery an authentic deed by a judge to do a holistic integral by look aspect outwardly, formal, material notarial deed associated with a task, authority the notary. 2) need to be made criteria and guidelines can be used the juridical for judges referred to forgery certificate in duty and position of a notary. 3) although there are freedom the judge in run/carry out of his rulings so the judges are not have to legalistik but prosecute at law in the country broadly including actual knowledge already established so that his ruling to reflect a sense of justice in society.
\end{abstract}

Keywords: The Application of; Interpreting; a Criminal Offense; an Authentic Deed.

\begin{abstract}
Abstrak
Artikel ini bertujuan untuk menganalisis penerapan Teori Penafsiran Hukum oleh hakim sebagai upaya perlindungan hukum terhadap Notaris, yaitu studi atas Putusan Hakim terhadap tindak pidana pemalsuan akta otentik. Jenis penelitian dalam artikel ini adalah doktrinal, sedangkan dilihat dari bentuknya termasuk penelitian evaluatif dan perspektif. Analisis yang digunakan logika deduksi. Dasar hukum dalam penjatuhan sanksi pidana terhadap Notaris dapat saja dilakukan namun di samping harus memenuhi rumusan pelanggaran yang tersebut dalam UUJN dan KUHP. Hakim dalam menerapkan sanksi pidana terhadap tindak pidana pemalsuan akta otentik harus dipenuhinya syarat-syarat antara lain sebagai berikut : (1) adanya perbuatan yang dapat dihukum dan memenuhi unsur-unsur yang dirumuskan dalam undang-undang; (2) perbuatan tersebut bertentangan dengan hukum/melawan hukum; (3) adanya kesalahan, baik
\end{abstract}


berupa kesengajaan (dolus) dan kelalaian (culpa). Rekomendasinya adalah : 1) Pemeriksaan adanya dugaan perbuatan pidana dalam pemalsuan akta otentik oleh Hakim harus dilakukan pemeriksaan yang holistik integral dengan melihat aspek lahiriah, formal, material Akta Notaris dikaitkan dengan tugas, wewenang, jabatan Notaris. 2) Perlu dibuat kriteria dan pedoman yang dapat dipakai landasan yuridis bagi hakim yang dimaksud pemalsuan akta dalam tugas dan jabatan notaris. 3) Meskipun ada kebebasan hakim dalam menjalankan/melaksanakan putusannya maka hakim tidak harus legalistik tetapi mengadili menurut hukum dalam arti yang luas termasuk aktualisasi pengertian-pengertian yang sudah mapan, sehingga putusannya dapat mencerminkan rasa keadilan (dalam) masyarakat.

Kata Kunci: Penerapan; Penafsiran; Tindak Pidana; Akta Otentik.

\section{A. Pendahuluan}

Kemandirian kekuasaan kehakiman atau independensi peradilan (the independent of judiciary) memang selalu terkait dengan konsep negara hokum (Frans Magnis Suseno, 1995 : 58-59), sebab salah satu syarat mutlak negara hukum adalah adanya jaminan akan kemandirian kekuasaan kehakiman atau kebebasan hakim. Hal ini menunjukkan bahwa unsur yang ensensial dari negara hukum ialah adanya jaminan kemandirian kekuasaan kehakiman atau independensi peradilan, yaitu bahwa di dalam melaksanakan peradilan, hakim bebas dari campur tangan kekuasaan ekstra yudisial baik kekuasaan eksekutif maupun legislatif dan kekuatan ekstra yudisial lainnya dalam masyarakat, meskipun kekuasaan kehakiman tersebut juga sebagai salah satu bagian atau alat dari kekuasaan negara.

Menurut Bagir Manan sebagaimana dikutip Ahmad Mujahidin, Kekuasaan lembaga peradilan yang merdeka mengandung makna larangan bagi kekuasaan ekstra yustisial mencampuri proses penyelenggaraan peradilan sebagai berikut : Larangan tersebut, hanya berlaku pada kekuasaan ekstra yustisial, tetapi kekuasaan lembaga peradilan tertentu, dimungkinkan mencampuri pelaksanaan fungsi peradilan lainnya. Kewenangan Pengadilan Tinggi untuk memeriksa perkara banding, wewenang Mahkamah Agung untuk melakukan pemeriksaan tingkat kasasi merupakan campur-tangan atas putusan yang telah diambil oleh suatu kekuasaan lembaga peradilan yang lebih rendah tingkatannya. Campur tangan lembaga lain dimungkinkan sepanjang UUD 1945 mengizinkan (Ahmad Mujahidin, 2007 : 61).

Oleh karena itu dalam ketentuan umum Pasal 1 Undang-Undang Nomor 48 Tahun 2009 tentang Kekuasaan Kehakiman disebutkan bahwa kekuasaan kehakiman adalah kekuasaan negara yang merdeka untuk menyelenggarakan peradilan guna menegakkan hukum dan keadilan berdasarkan Pancasila dan Undang-Undang Dasar Negara Republik Indonesia Tahun 1945, demi terselenggaranya negara hukum Republik Indonesia. Meskipun demikian kebebasan hakim dalam melaksanakan wewenang yudisial bersifat tidak mutlak karena tugas hakim adalah untuk menegakkan hukum dan keadilan berdasarkan Pancasila, sehingga putusannya mencerminkan rasa keadilan rakyat Indonesia bukan keadilan subyektif menurut pengertian atau kehendak hakim semata (Yahya Harahap, 2008 : 2).

Dalam menjalankan fungsi dan kekuasaannya, dalam ketentuan Pasal 18 UU Nomor 48 Tahun 2009 tentang Kekuasaan Kehakiman disebutkan dilakukan oleh sebuah Mahkamah Agung dan badan peradilan yang berada di bawahnya dalam lingkungan peradilan umum, lingkungan peradilan agama, lingkungan peradilan militer, lingkungan 
peradilan tata usaha negara dan oleh sebuah Mahkamah Konstitusi.

Pengadilan sebagai salah satu pranata dari hukum modern, merupakan suatu mekanisme yang disediakan Negara untuk menyelesaikan sengketa ataupun bentuk permasalahan hukum yang diajukan oleh warga masyarakat. Sehingga dalam hal ini Pengadilan (Hakim) tidak dapat menolak suatu perkara yang diajukan kepadanya dengan alasan tidak terdapat adanya hukum yang mengatur untuk itu. Di sisi lain ada beberapa alasan yang mendorong warga masyarakat untuk menyelesaikan sengketa (ataupun permasalahan hukumnya) ke Pengadilan, yaitu : (1) Kepercayaan, bahwa di tempat itu akan memperoleh keadilan seperti mereka kehendaki. (2) Kepercayaan, bahwa Pengadilan merupakan lembaga yang mengekspresikan nilai-nilai kejujuran, mentalitas yang tidak korup dan nilai-nilai utama lainnya. (3) Bahwa waktu dan biaya yang mereka keluarkan tidak siasia. (4) Bahwa Pengadilan merupakan tempat bagi orang yang benar-benar memperoleh perlindungan hokum (Adi Sulistiyono, 2006 $: 18)$.

Dalam hal kewenangan untuk menjalankan kekuasaan kehakiman, Leopold Pospisil yang dikutip Achmad Ali (Esmi Warassih, 2005 : 64) mengemukakan ada 4 (empat) atribut hukum, yaitu :

1. Hukum merupakan putusan dari pihakpihak yang berkuasa dalam masyarakat, putusan-putusan mana ditujukan untuk mengatasi ketegangan-ketegangan yang terjadi di dalam masyarakat (attribute of authority),

2. Putusan-putusan yang mempunyai daya jangkau yang panjang untuk masa mendatang (attribute of intention of universal application),

3. Putusan-putusan pengawasan yang harus berisi kewajiban-kewajiban pihak pertama terhadap pihak-pihak kedua dan sebaliknya (attribute of obligation), dan
4. Putusan-putusan dari pihak yang berkuasa harus dikuatkan dengan sanksi yang didasarkan kepada kekuasaan masyarakat yang nyata (attribute of sanction).

Kemandirian pengadilan adalah adanya kemampuan pengadilan untuk mewujudkan keempat atribut hukum itu dalam kenyataannya., dimana pengadilan memahami dirinya juga memahami masyarakat dengan cara-cara yang memungkinkan peradilan mereproduksi diri sendiri dalam penyelesaian sengketa atau perkara yang masuk dalam yuridiksinya. Penyelesaian suatu perkara atau sengketa dalam beracara di Pengadilan, para hakim dan pejabat badan peradilan dalam menjalankan kewenangannya terdapat rambu-rambu aturan hukum formal, maupun hukum materiil. Kekuasaan peradilan dalam melaksanakan kewenangannya terikat pada aturan hukum materiil dan hukum formil/ hukum acara sebagai dasar normatif dalam menjalankan kebebasan kekuasaan peradilan dan atau kebebasan hakim dalam proses peradilan.

Manifestasi terwujudnya dari perlakukanperlakuan yang dijamin oleh ketentuan hukum yang terlaksana dengan baik, antara lain ialah persamaan di muka hukum, hak atas pemeriksaan pengadilan yang tidak memihak, demikian pula tentang hak untuk tidak dianggap bersalah sebelum diputuskan oleh hakim. Berbicara tentang hakim dan putusan hakim di Indonesia tidak bisa dilepaskan dari pembicaraan tentang keadilan dan kepastian hukum, karena keduanya merupakan unsur yang ensensial dalam hukum, termasuk putusan hakim. Idealnya dalam sebuah putusan hakim harus dijiwai oleh ketiga nilai dasar hukum yaitu keadilan, kepastian dan kemanfaatan. Namun realitas menunjukkan bahwa seringkali terjadi pertentangan antara nilai-nilai yang satu dengan yang lainnya, misalnya antara keadilan dan kepastian hukum atau antara kemanfaatan dan kepastian hukum. Hal ini yang menyebabkan ketiga 
unsur ensensial hukum tersebut sulit terwujud secara bersama-sama, dan bahkan lebih sering terjadi konflik antara ketiganya, dimana pada kenyataan hal ini disebabkan peraturan undang-undang cenderung mengabaikan realitas sosial dan bahkan adanya ketentuan undang-undang yang tidak relevan lagi dengan perkembangan masyarakat.

Disisi yang lain kualitas keputusan yang diambil oleh hakim mempunyai pengaruh yang penting pada kewibawaan dan kredibilitas lembaga peradilan, sehingga rendahnya kualitas keputusan atau vonis hakim jelas akan menurunkan wibawa dan kredibilitas pengadilan, namun hakim adalah manusia yang resistensinya terbatas bila menghadapi pengaruh-pengaruh yang senantiasa berada di sekelilingnya, hal ini yang sering kali menyebabkan hakim tidak bisa berpikir obyektif dan bebas ketika hendak mengambil suatu keputusan atas suatu perkara (Esmi Warassih, 2005 : 66).

Dalam melaksanakan tugasnya tersebut, yaitu mengadili perkara, hakim bukan hanya sebagai mulut atau corong undang-undang, melainkan selalu harus menafsirkan atau fakta-fakta hukum yang terjadi dipersidangan, diterapkan dengan ketentuan undang-undang, sehingga mendapatkan keyakinan berdasarkan ketentuan yang berlaku. Disamping itu menurut Pasal 10 UU Nomor 48 Tahun 2009 tentang Kekuasaan Kehakiman disebutkan bahwa Pengadilan dilarang menolak untuk memeriksa, mengadili dan memutuskan perkara yang diajukan dengan dalih bahwa hukum tidak ada atau kurang jelas, melainkan wajib untuk memeriksa dan mengadilinya. Oleh karena itu Hakim diwajibkan menggali, mengikuti dan memahami nilai-nilai hukum dan rasa keadilan yang hidup dalam masyarakat sebagaimana diatur dalam Pasal 5 sebagai berikut :

(1) Hakim dan hakim konstitusi wajib menggali, mengikuti, dan memahami nilai-nilai hukum dan rasa keadilan yang hidup dalam masyarakat;

(2) Hakim dan hakim konstitusi harus memiliki integritas dan kepribadian yang tidak tercela, jujur, adil, profesional, dan berpengalaman di bidang hukum;

(3) Hakim dan hakim konstitusi wajib mentaati Kode Etik dan Pedoman Perilaku Hakim.

Hakim dalam memeriksa, memutus dan mengadili perkara harus berdasarkan hukum dan juga keyakinannya, bukan berdasarkan logika hukum. Purwoto S. Gondosubroto yang ditulis oleh P. Wignyosumarto (P. Wignyosumarto, 2006 : 69) menyatakan sebagai berikut : (1) Dalam kasus yang hukumnya atau undang-undangnya sudah jelas, hakim hanya menerapkan hukumnya (hakim menjadi terompet undang-undang). (2) Dalam kasus yang hukum dan undangundangnya tidak atau belum jelas, hakim harus menafsirkan hukum atau undang-undang, melalui cara-cara atau metode penafsiran yang berlaku dalam ilmu hukum. (3) Dalam kasus dimana terjadi pelanggaran/penerapan hukum yang bertentangan dengan hukum/ undang-undang yang berlaku, hakim akan menggunakan hak mengujinya berupa formele toetsingrecht atau meteriele toetsingrecht.

Berkaitan dengan kewajiban hakim untuk menggali, mengikuti dan memahami nilai-nilai hukum dan rasa keadilan yang hidup dalam masyarakat, maka pemakaian teori-teori penemuan dan penafsiran hukum dapat dilakukan dalam memutuskan suatu perkara untuk kasus-kasus yang hukum/ undang-undangnya tidak/belum jelas. Namun pemakaian teori penemuan dan penafsiran hukum harus dilakukan dengan cara-cara atau metode penafsiran yang berlaku dalam ilmu hukum. Alasan digunakannya teori penafsiran hukum oleh hakim dalam mengadili suatu perkara disebabkan hampir tidak mungkin hukum bisa dijalankan tanpa membuka pintu 
bagi penafsiran. Penafsiran hukum merupakan aktifitas yang mutlak terbuka untuk dilakukan, sejak hukum berbentuk tertulis, dimana sebuah adagium yang menyebutkan bahwa membaca hukum adalah menafsirkan hukum. Teks hukum sudah jelas adalah satu cara saja bagi pembuat hukum untuk bertindak pragmatis seraya diam-diam mengakui bahwa ia mengalami kesulitan untuk memberikan penjelasan (Anton Freddy Susanto, 2005 : 1).

Adapun asas yang mewadahi Hakim di dalam menemukan hukum itu adalah sebagaimana tertuang di dalam ketentuan Pasal 10 Undang-Undang Nomor 48 Tahun 2009 Tentang Kekuasaan Kehakiman yang menegaskan bahwa "Pengadilan tidak boleh menolak untuk memeriksa, mengadili dan memutus suatu perkara yang diajukan dengan dalih bahwa hukum tidak ada atau kurang jelas, melainkan wajib untuk memeriksa dan mengadilinya". Melalui asas-asas hukum tersebut menjadi jelas bahwa tidak ada suatu persoalan atau permasalahan hukum yang tidak ada hukum untuk mengaturnya. Bagi Hakim selalu ada dasar dan alasannya di dalam memutus perkara yang diajukan kepadanya. Persoalannya bukan lagi kepada ada-tidaknya hukum atau jelas-tidaknya hukum bagi Hakim di dalam memutus suatu perkara, melainkan lebih kepada bagaimana Hakim menemukan hukum itu (Charles Himawan, 2006 : 24).

Realitas menunjukkan bahwa seringkali terjadi pertentangan antara nilai-nilai yang satu dengan yang lainnya, misalnya antara keadilan dan kepastian hukum atau antara kemanfaatan dan kepastian hukum. Hal ini yang menyebabkan ketiga unsur ensensial hukum tersebut sulit terwujud secara bersamasama, dan bahkan lebih sering terjadi konflik antara ketiganya, dimana pada kenyataan hal ini disebabkan peraturan undang-undang cenderung mengabaikan realitas sosial dan bahkan adanya ketentuan undang-undang yang tidak relevan lagi dengan perkembangan masyarakat.
Disisi yang lain kualitas keputusan yang diambil oleh hakim mempunyai pengaruh yang penting pada kewibawaan dan kredibilitas lembaga peradilan. Sehingga rendahnya kualitas keputusan atau vonis hakim jelas akan menurunkan wibawa dan kredibilitas pengadilan, namun hakim adalah manusia yang resistensinya terbatas bila menghadapi pengaruh-pengaruh yang senantiasa berada di sekelilingnya, sehingga hal ini yang sering kali menyebabkan hakim tidak bisa berpikir obyektif dan bebas ketika hendak mengambil suau keputusan atas suatu perkara.

Kebebasan hakim dalam melaksanakan wewenang yudisial bersifat tidak mutlak karena tugas hakim adalah untuk menegakkan hukum dan keadilan berdasarkan Pancasila, sehingga putusannya mencerminkan rasa keadilan rakyat Indonesia bukan keadilan subyektif menurut pengertian atau kehendak hakim semata. Meskipun demikian dalam pelaksanaannya kebebasan dan kemandirian yang diberikan kekuasaan kehakiman tersebut tidak dapat dilaksanakan sebagaimana mestinya, karena dalam menjalankan kemandiriannya hakim dibatasi oleh sistem pemerintahan, politik dan ekonomi serta peraturan perundang-undangan yang mengatur kemerdekaan tersebut.

Menurut Van Doom (Satjipto Rahardjo, tanpa tahun : 26-27), dalam kedudukannya sebagai pemegang fungsi dalam rangka suatu organisasi, seorang penegak hukum cenderung untuk menjalankan fungsinya itu menurut penafsirannya sendiri yang dilatarbelakangi oleh berbagai faktor, misalnya kepribadiannya, ekonominya, pandangan hidupnya, dan sebagainya. Disisi yang lain, karena rutinitasnya pekerjaaannya membuat keputusan atau vonis, seringkali hakim mengabaikan standar normatif yang harus ditempuh untuk membuat suatu keputusan, kondisi ini dapat dilihat dari dasar pertimbangan hukum yang diambil untuk membuat suatu keputusan yang terkesan asal jadi/asal-asalan, apalagi kalau hal 
tersebut hanya menyangkut perkara-perkara yang rutin setiap hari ditanganinya, padahal kekuatan moral suatu keputusan hakim terletak pada pertimbang-pertimbangannya itu. Pertimbangan-pertimbangan hukum yang dipakai oleh hakim dapat menggunakan teori penafsiran hukum dan/atau teori penemuan hukum .

Berdasarkan hal-hal tersebut di atas, dalam artikel ini hendak dibahas dasar hukum pertimbangan hakim dalam menjatuhkan putusan pada tindak pidana pemalsuan akta otentik dan bagaimana penerapan teori penafsiran hukum oleh hakim dalam pertimbangannya terhadap kasus pemalsuan akta otentik.

\section{B. Metode Penelitian}

Penelitian dalam artikel ini adalah termasuk jenis penelitian hukum doktrinal, sedangkan dilihat dari bentuknya termasuk penelitian yang evaluative dan prespektif. Sifat penelitian ini merupakan penelitian adalah eksploratif. Analisis berdasarkan logika deduksi. Pendekatan yang dipakai adalah pendekatan peraturan perundang-undangan (Statute Approach) dan pendekatan kasus (Case Approach). Jenis data yang digunakan adalah Data Sekunder, yang terdiri dari : bahan hukum primer, sekunder dan tersier, sedangkan sumber datanya berasal dari peraturan perundang-undangan dan putusan pengadilan, studi kepustakaan, bahan-bahan dokumenter, tulisan-tulisan ilmiah dan sumber-sumber tertulis lainnya.

\section{Hasil Penelitian dan Pembahasan}

1. Dasar Hukum Pertimbangan Hakim dalam Menjatuhkan Putusan Terhadap Notaris Yang Melakukan Tindak Pidana Pemalsuan Akta Otentik

Pertimbangan hakim merupakan salah satu aspek terpenting untuk menentukan terwujudnya suatu putusan hakim yang mengandung keadilan, kepastian hukum dan bermanfaat bagi pihak yang bersangkutan. Merujuk pada teori dasar pertimbangan hakim, suatu putusan dapat dikatakan baik atau sempurna hendaknya putusan tersebut dapat diuji dengan 4 kriteria dasar pertanyaan (the four way test) berupa : Benarkah putusanku ini?; Jujurkah aku dalam mengambil keputusan?; Adilkah putusan ini bagi para pihak?; Apakah putusan ini bermanfaat? (Lilik Mulyadi, 2007 : 136) Pedoman pemberian pidana (strafftoemeting-leidraad) akan memberikan kemudahan bagi hakim untuk menetapkan pemidanaannya, setelah terbukti bahwa apa yang dituduhkan terhadap tertuduh telah terbukti. Daftar tersebut memuat hal-hal yang bersifat subjektif yang menyangkut hal-hal yang diluar pembuat. Penjatuhan pidana diharapkan lebih proporsional dan lebih dipahami mengapa pidana seperti itu yang dijatuhkan (Muladi dan Barda Nawawi Arif, 1998 : 67).

Berdasarkan Pasal 20 ayat (2) huruf a dan Pasal 23 Undang-Undang Nomor 48 Tahun 2009 tentang Kekuasaan Kehakiman, hakim pada peradilan tingkat kasasi yang dilakukan di Mahkamah Agung telah sesuai. Pasal 20 ayat (2) huruf a Undang-Undang Nomor 48 Tahun 2009 tentang Kekuasaan Kehakiman berbunyi : "Mahkamah Agung berwenang mengadili pada tingkat kasasi terhadap putusan yang diberikan pada tingkat terakhir oleh pengadilan di semua lingkungan peradilan yang berada di bawah Mahkamah Agung, kecuali undang-undang menentukan lain". Demikian juga pada Pasal 23 Undang-Undang Nomor 48 Tahun 2009 tentang Kekuasaan Kehakiman berbunyi : "Putusan pengadilan dalam tingkat banding dapat dimintakan kasasi kepada 
Mahkamah Agung oleh pihak-pihak yang bersangkutan, kecuali undang-undang menentukan lain".

Pengajuan upaya hukum kasasi harus tepat dan dapat dilakukan karena telah memenuhi tenggang waktu dan syaratsyarat secara formil. Kasasi merupakan salah satu upaya hukum biasa dan merupakan hak asasi yang diberikan oleh peraturan perundang-undangan kepada salah satu pihak atau kedua belah pihak yang berperkara terhadap suatu putusan Pengadilan Tinggi. Kasasi diajukan bila para pihak tidak puas dengan isi putusan Pengadilan Tinggi kepada Mahkamah Agung melalui Pengadilan Negeri dimana putusan tersebut dijatuhkan.

Kebebasan hakim untuk menjatuhkan hukuman dalam proses peradilan didasarkan pada Pasal 3 ayat (1) dan (2) Undang-Undang Nomor 48 Tahun 2009 tentang Kekuasaan Kehakiman yang menyatakan dalam Pasal 3 sebagai berikut : (1) Dalam menjalankan tugas dan fungsinya, hakim dan hakim konstitusi wajib menjaga kemandirian peradilan; (2) Segala campur tangan dalam urusan peradilan oleh pihak lain di luar kekuasaan kehakiman dilarang, kecuali dalam hal-hal sebagaimana dimaksud dalam UndangUndang Dasar Negara Republik Indonesia Tahun 1945. Terdapat dua kemungkinan yang akan terjadi terhadap suatu putusan pengadilan tinggi yang dimohonkan kasasi, yaitu: (1) Menolak permohonan kasasi. Putusan ini diberikan apabila tidak terbuktinya alasan-alasan yang diajukan kasasi. (2) Mengabulkan permohonan kasasi. Putusan ini diberikan apabila terbuktinya alasan-alasan pengajuan kasasi dan Mahkamah Agung membatalkan putusan pengadilan sebelumnya. Terhadap pembatalan terhadap putusan pengadilan sebelumnya oleh hakim Mahkamah Agung pada tingkat kasasi, ada beberapa kemungkinan yang dapat diberikan, yaitu: (1) Mengadili sendiri perkara tersebut apabila putusan dibatalkan karena tidak diterapkannya peraturan hukum sebagaimana mestinya. (2) Memberikan petunjuk untuk pemeriksaan kembali oleh pengadilan yang memutus perkara yang bersangkutan atau menetapkan perkara tersebut diperiksa oleh pengadilan setingkat yang lain apabila putusan tersebut dibatalkan karena cara mengadili yang tidak sesuai dengan ketentuan undangundang; (3) Menetapkan pengadilan atau hakim lain mengadili perkara tersebut apabila putusan dibatalkan karenaketidakwenangan pengadilan atau hakim.

Adapun hal-hal yang dipertimbangkan oleh hakim dalam menjatuhkan pidana dengan memperhatikan tujuan pemidanaan yaitu : (1) Mencegah terjadinya tindak pidana dengan menegakkan norma hukum demi pengayoman masyarakat; (2) Memasyarakatkan terpidana melalui pembinaan sehingga menjadi orang yang baik dan berguna; (3) Menyelesaikan konflik yang timbul akibat terjadinya tindak pidana, memulihkan keseimbangan dan menciptakan perdamaian dalam masyarakat; (4) Membebaskan terpidana dari rasa bersalah; (5) Tujuan pemidanaan bukan untuk menderitakan dan merendahkan martabat manusia. Disamping itu Hakim wajib untuk menegakkan hukum dan tidak memihak. Hakim dalam memberikan suatu keadilan harus terlebih dahulu menelaah kebenaran peristiwa tersebut dan menghubungkannya dengan hukum yang berlaku. Hakim dalam menjatuhkan putusan berpedoman apada 3 hal, yaitu : Unsur yuridis, yang merupakan unsur utama dan pertama; Unsur filosofis, berintikan apada keadilan dan kebenaran; Unsur sosiologis, yaitu pertimbangan yang didasarkan pada tata 
nilai budaya yang hidup dan berkembang dalam masyarakat.

Menurut Moeljatno, proses penjatuhan hukuman oleh hakim dalam perkara pidana dilakukan dalam beberapa tahap (Ahmad Rifai, 2010 : 96), yaitu (1) Tahap menganalisis perbuatan pidana. Tahap ini adalah tahap dimana hakim menganalisis apakah terdakwa melakukan perbuatan pidana atau tidak, yang dipandang primer adalah segi masyarakat, yaitu perbuatan tersebut diatur sebagai suatu rumusan aturan pidana. (2) Tahap menganalisis pertanggungjawaban pidana. Pada tahap ini jika terdakwa dinyatakan terbukti melakukan suatu perbuatan pidana, hakim akan menganalisis apakah terdakwa mampu untuk mempertanggungjawabkan perbuatan pidana yang dilakukannya. (3) Tahap penentuan pemidanaan. Hakim akan menjatuhkan pidana apabila pelaku telah memenuhi unsur-unsur dari pasal undang-undang yang dilanggar.

Dasar pertimbangan hukum yang dipakai oleh Hakim dalam kasus pemalsuan akta otentik disimpulkan sebagai berikut :

1) Sanksi pidana terhadap Notaris harus dilihat dalam rangka menjalankan tugas jabatan Notaris, artinya dalam pembuatan atau prosedur pembuatan akta harus berdasarkan kepada aturan hukum yang berlaku yang dalam hal ini Undang-Undang Jabatan Notaris (UUJN), sehingga apabila semua tata cara pembuatan akta sudah ditempuh maka suatu hal yang tidak mungkin secara sengaja Notaris melakukan suatu tindak pidana yang berkaitan dengan akta tersebut. Pengertian sengaja (dolus) yang dilakukan Notaris, merupakan suatu tindakan yang disadari, atau direncanakan dan diinsyafi segala akibat hukumnya.
2) Batasan yang dijadikan dasar untuk memidanakan Notaris merupakan aspek formal dari akta Notaris dan seharusnya digunakan UndangUndang Jabatan Notaris (UUJN). Hal ini disebabkan ruang lingkup jabatan Notaris yaitu membuat alat bukti yang diinginkan oleh para pihak untuk suatu tindakan hukum tertentu berdasarkan permintaan dari para pihak. Notaris membuat akta yang dimaksud berdasarkan alat bukti atau keterangan atau pernyataan para pihak yang dinyatakan atau diterangkan atau diperlihatkan dihadapan Notaris, selanjutnya dengan berpijak pada aturan hukum atau tata cara atau prosedur pembuatan akta dan aturan hukum yang berkaitan kemudian Notaris membingkainya secara lahiriah, formil dan meteriil dalam bentuk akta Notaris. Peran Notaris juga memberikan nasihat hukum yang sesuai dengan permasalahan yang ada, dan apapun nasihat hukum yang diberikan kepada para pihak dan kemudian dituangkan kedalam akta yang bersangkutan tetap sebagai keinginan atau keterangan para pihak yang bersangkutan, tidak dan bukan sebagai keterangan atau pernyataan Notaris.

3) Notaris hanya sekedar mengkonstatir saja apa yang diinginkan atau dikehendaki oleh penhadap yang bersangkutan, dengan cara mencatat, kemudian menyusunnya agar sesuai dengan peraturan hukum yang berlaku. Apabila sudah sesuai dengan kehendak penghadap, maka penghadap diminta untuk membubuhkan tandatangannya serta menulis nama terangnya. Sehingga jikadikemudian hari ternyata terbukti bahwa yang menghadap Notaris tersebut bukan orang yang sebenarnya atau orang 
yang mengaku asli tetapi orang yang sebenarnya tidak pernah menghadap notaris, maka pertanggungjawaban pidana tidak dapat dibebankan kepada Notaris karena unsur unsur kesalahannya tidak ada. Oleh karena itu memidanakan Notaris berdasarkan aspek-aspek tersebut tanpa melakukan penelitian atau pembuktian yang mendalam dengan mencari unsur-unsur kesalahan atau kesengajaan dari Notaris merupakan suatu tindakan tanpa dasar hukum yang dapat dipertanggungjawabkan. Meskipun aspek-aspek formal akta Notaris dapat saja dijadikan dasar atau batasan untuk memidanakan Notaris, jika sepanjang aspek-aspek formal tersebut terbukti secara sengaja (kesadaran dan keinsyafan dan direncanakan) bahwa akta yang dibuat di hadapan dan oleh Notaris untuk dijadikan suatu alat melakukan tindak pidana.

\section{Penerapan Teori Penafsiran Hukum oleh Hakim dalam Pertimbangannya Terhadap Kasus Pemalsuan Akta Otentik}

Penegakan hukum merupakan faktor penting dalam mencegah dan memberantas tindak pidana/kejahatan mengingat Indonesia merupakan negara hukum berdasarkan Pasal 1 ayat (3) Undang-Undang Dasar Negara Republik Indonesia Tahun 1945 (UUD 1945). Penegakan hukum bertujuan untuk memberikan perlindungan bagi masyarakat dari segala tindakan kriminal yang mungkin akan terjadi sehingga dari sini negara berkewajiban untuk mengadakan pencegahan dan penanggulangan kejahatan dengan menerapkan hukum pidana. Negara dalam hal ini bertindak selaku penguasa berhak menjatuhkan sanksi pidana dan satusatunya subyek hukum yang mempunyai hak untuk menghukum dalam rangka melaksanakan penegakan hukum (ius pundi). Pada penerapan hukum pidana, negara mendelegasikan wewenangnya untuk menjatuhkan sanksi pidana kepada para penegak hukum yang bekerja dalam suatu sistem bernama sistem peradilan pidana (criminal justice) (Mardjono Reksodiputro, 2007 : 84).

Salah satu sub sistem pendukung yang berperan sangat penting di dalam pelaksanaan sistem peradilan pidana adalah pengadilan. Hakim sebagai penegak hukum berwenang untuk mengambil dan menjatuhkan putusan yang mempunyai akibat hukum bagi pihak lain mempunyai kebebasan yang sangat luas untuk menentukan jenis pidana yang sesuai dengan kehendaknya (Evi Hartanti, 2014 : 21). Realitas menunjukkan bahwa seringkali terjadi pertentangan antara nilai-nilai yang satu dengan yang lainnya, misalnya antara keadilan dan kepastian hukum atau antara kemanfaatan dan kepastian hukum. Hal ini yang menyebabkan ketiga unsur ensensial hukum tersebut sulit terwujud secara bersama-sama, dan bahkan lebih sering terjadi konflik antara ketiganya, dimana pada kenyataan hal ini disebabkan peraturan undang-undang cenderung mengabaikan realitas sosial dan bahkan adanya ketentuan undang-undang yang tidak relevan lagi dengan perkembangan masyarakat.

Kebebasan hakim dalam melaksanakan wewenang yudisial bersifat tidak mutlak karena tugas hakim adalah untuk menegakkan hukum dan keadilan berdasarkan Pancasila, sehingga putusannya mencerminkan rasa keadilan rakyat Indonesia bukan keadilan subyektif menurut pengertian 
atau kehendak hakim semata. Meskipun demikian dalam pelaksanaannya kebebasan dan kemandirian yang diberikan kekuasaan kehakiman tersebut tidak dapat dilaksanakan sebagaimana mestinya, karena dalam menjalankan kemandiriannya hakim dibatasi oleh sistem pemerintahan, politik dan ekonomi serta peraturan perundang-undangan yang mengatur kemerdekaan tersebut. Disisi yang lain kualitas keputusan yang diambil oleh hakim mempunyai pengaruh yang penting pada kewibawaan dan kredibilitas lembaga peradilan. Sehingga rendahnya kualitas keputusan atau vonis hakim jelas akan menurunkan wibawa dan kredibilitas pengadilan, namun hakim adalah manusia yang resistensinya terbatas bila menghadapi pengaruhpengaruh yang senantiasa berada di sekelilingnya, sehingga hal ini yang sering kali menyebabkan hakim tidak bisa berpikir obyektif dan bebas ketika hendak mengambil suau keputusan atas suatu perkara.

Munculnya pertimbangan hakim yang didasarkan pada rasa keadilan dan mengabaikan kepastian hukum dalam menjatuhkan pidana bersyarat terhadap pelaku tindak pidana korupsi bisa saja dibenarkan karena apabila terjadi pertentangan antara keadilan dengan kepastian hukum maka keadilanlah yang diutamakan. Hal tersebut sesuai dengan pendapat Roeslan Saleh yang selanjutnya dikutip oleh Mardjono Reksodiputro yang mengatakan bahwa keadilan dan kepastian sama-sama merusak tujuan hukum yang kerap kali tidak sejalan satu sama lainnya dan sulit untuk dihindari dalam praktek hukum, dana apabila dalam keadilan dan kepastian saling mendesak pada kejadian konkrit, maka hakim harus sejauh mungkin harus mengutamakan keadilan di atas kepastian hukum (Mardjono
Reksodiputro, 2009 : 321).

Ditegaskan oleh Merriam Webster's Dictionary of Law, bahwa "judicial power : the power granted to the judicial branch of a govenment, sehingga kebebasan hakim dalam melaksanakan kewenangan yudisialnya bersifat tidak mutlak karena hakim bertugas untuk menegakkan hukum dan keadilan yang didasarkan pada Pancasila, sehingga putusannya mencerminkan rasa keadilan rakyat Indonesia bukan keadilan subyektif menurut pengertian atau kehendak hakim semata (Yahya Harahap, 2008 : 2).

Prinsip kekuasaan kehakiman yang merdeka menimbulkan pertanyaan dalam praktek ketatanegaraan Indonesia. Apakah merdeka dalam hal ini merupakan merdeka dari keterikatan pada peraturan yang ada, sehingga kekuasaan kehakiman "membentuk" sendiri ketentuan-ketentuan untuk masyarakat (khususnya bagi yang menyelesaikan masalah di peradilan) ataukah yang lazimnya menumbuhkan ekses, merdeka dalam arti masing-masing hakim dapat menentukan tata-caranya sendiri baik mengenai tempat, waktu, maupun cara mengambil keputusan. Kekuasaan kehakiman dalam hal ini adalah tidaklah dapat dikatakan sebagai kekuasaan yang merdeka dalam arti terlepas dari pengaruh kekuasaan legislative, tetapi kekuasaan tersebut dibatasi oleh kekuasaan (kepentingan) rakyat yang tercermin dalam bentuk undang-undang (Padmo Wahyono, 1986 :76).

Hakim memang memiliki kebebasan dalam menjatuhkan putusan, namun tidak boleh menjatuhkan hukuman lebih rendah ataupun lebih tinggi dari batas hukuman yang telah ditentukan oleh undang-undang. Kebebasan hakim adalah bebas dalam memeriksa dan memutus 
perkara sesuai dengan keyakinannya dan bebas dari pengaruh pihak ekstra yudisial. Hakim bebas menggunakan alat-alat bukti, bebas menilai alat bukti maupun menilai terbukti tidaknya suatu peristiwa konkret berdasarkan pada alat bukti yang ada. Selain itu, hakim juga bebas berkeyakinan dalam hal jenis hukuman apa yang akan dijatuhkan (Sudikno Mertokusumo, 2008 : 122). Putusan yang dibuat oleh hakim harus bersumber pada kemampuannya untuk berpikir dan berkehendak secara bebas namun dalam pembatasan tanggungjawab, artinya putusan yang dibuat dapat dipertanggungjawabkan atas dasar harapan orang lain tanpa mengurangi objektivitasnya (Ahmad Kamil, 2012 : 172). Hakikat dari independensi atau kemandirian diikat dan dibatasi oleh rambu-rambu tertentu, sehingga dalam konferensi internasional Commission of Juurist dikatakan bahwa "Independence does not mean that the judge is entitled to act in an arbitrary manner". Batasan atau rambu-rambu yang utama harus diingat dan diperhatikan dalam implementasi kebebasan adalah aturan-aturan hukum itu sendiri. Ketentuan-ketentuan hukum baik dari segi prosedural maupun substansial/materiil telah memberikan batasan bagi kekuasaan kehakiman agar tidak melanggar hukum dan bertindak sewenang-wenang dalam melakukan independensinya. Kebebasan dan independensi pada dasarnya merupakan kedua sisi koin mata uang yang saling melekat, artinya, tidak ada kebebasan mutlak tanpa tanggung jawab.

Kebebasan hakim dibatasi oleh tanggungjawab dimana salah satu bentuk tanggungjawab yang perlu disadari adalah pertanggungjawaban kepada masyarakat (social accountabilty) karena pada dasarnya tugas dari badanbadan kehakiman atau peradilan adalah melaksanakan public service dibidang memberikan keadilan bagi masyarakat pencari keadilan (Paulus Efendi Lotulung, 2003 : 7). Dalam rangka interpretasi hukum ini, dikenal bermacam-macam metode interpretasi (penafsiran), yaitu : 1) Penafsiran Gramatikal, adalah menafsirkan kata-kata dalam undang-undang sesuai kaidah bahasa dan kaidah hukum tatabahasa; 2) Penafsitan Historis, yaitu setiap ketentuan peraturan perundangundangan mempunyai sejarahnya sendiri; 3) Penafsiran Sistematis, adalah metode yang menafsirkan undang-undang sebagai bagian dari keseluruhan sistem perundangundangan; 4) Penafsiran Sosiologis/ Teleologis, yaitu apabila makna undangundang ditetapkan berdasarkan tujuan kemasyarakatannya; 5) Penafsiran Ekstensif, adalah metode penafsiran yang membuat interpretasi melebihi batasbatas hasil interpretasi gramatikal; dan 6) Penafsiran Otentik atau Resmi, yaitu Hakim tidak diperkenankan melakukan penafsiran dengan cara lain, selain dari apa yang telah ditentukan pengertiannya didalam undang-undang itu sendiri (Purwoto S. Gandasubrata, 1998 : 53-57).

Atas dasar itu, maka penilaian mengenai putusan yang dibuat oleh hakim itu bertanggung jawab dicocokkan dengan tingkat kepuasan masyarakat selaku pemberi kebebasan sosial dengan menilai apakah putusan itu telah memenuhi rasa keadilan atas kebebasan sosial yang dilanggar oleh orang yang dikenai putusan hakim (Ahmad Kamil, 2012 : 173). Salah satu teori kebebasan Hakim dikemukakan oleh Franz Magnis-Suseno yang menyatakan putusan hukum yang dibuat oleh hakim harus didasarkan pada pertimbangan-pertimbangan yang matang dengan berangkat dari kebebasan eksistensialnya yang mendapat tempat dalam kebebasan sosial yang diberikan. 
Pertimbangan selanjutnya adalah bahwa putusan hakim tersebut harus dapat dipertanggungjawabkan dengan memperhatikan suara hati dan moral otonom yang ada pada dirinya sendiri. Berdasarkan pertimbangan-pertimbangan tersebut, hakim akan dapat menghasilkan putusan yang memuaskan kebebasan eksistensialnya maupun kebebasan sosialnya serta rasa keadilan secara keseluruhan (Ahmad Kamil, 2012: 173).

\section{Simpulan}

1. Dasar hukum dalam penjatuhan sanksi pidana terhadap Notaris dapat saja dilakukan namun di samping harus memenuhi rumusan pelanggaran yang tersebut dalam UUJN juga memenuhi rumusan pelanggaran yang ada dalam KUHP. Pelanggaran oleh Notaris harus diukur berdasarkan UUJN artinya apakah perbuatan yang dilakukan oleh Notaris melanggar ketentuan pasal yang diatur UUJN karena ada kemungkinan menurut UUJN bahwa akta yang bersangkutan telah sesuai tetapi perbuatan tersebut merupakan perbuatan tindak pidana. Pemidanaan terhadap Notaris dapat saja dilakukan dengan batasan, jika : (1) ada tindakan hukum dari Notaris terhadap aspek formal akta yang sengaja, penuh kesadaran dan keinsyafan serta direncanakan, bahwa akta dibuat di hadapan Notaris atau oleh Notaris bersama-sama/sepakat untuk dijadikan dasar untuk melakukan suatu tindak pidana dan/atau ada tindakan hukum dari Notaris dalam membuat akta di hadapan atau oleh Notaris yang jika diukur berdasarkan UUJN tidak sesuai/ pelanggaran jabatan notaris. Hakim dalam menerapkan sanksi pidana terhadap tindak pidana pemalsuan akta otentik harus dipenuhinya syarat-syarat antara lain sebagai berikut : yaitu (1) adanya perbuatan yang dapat dihukum dan memenuhi unsur-unsur yang dirumuskan dalam undang-undang; (2) perbuatan tersebut bertentangan dengan hukum/ melawan hukum; (3) adanya kesalahan, baik berupa kesengajaan (dolus) dan kelalaian (culpa).

2. Hakim dalam menjatuhkan putusan terhadap kasus pemalsuan akta otentik dapat menggunakan teori penafsiran hukum baik melalui penafsiran gramatikal, penafsiran historis, penafsiran sistematis, penafsiran soliologis/teleologis, penafsiran ekstensif dan penafsiran otentik/resmi.

\section{E. Saran}

1. Pemeriksaan adanya dugaan perbuatan pidana dalam pemalsuan akta otentik oleh Hakim seyogyanya dilakukan pemeriksaan yang holistik integral dengan melihat aspek lahiriah, formal, material Akta Notaris dikaitkan dengan tugas, wewenang, jabatan Notaris.

2. Mahkamah Agung perlu membuat kriteria dan pedoman yang dapat dipakai landasan yuridis bagi hakim yang dimaksud pemalsuan akta dalam tugas dan jabatan notaris. Akan tetapi perlu dicatat bahwa pedoman tersbut tidaklah harus membatasi kebebasan hakim dalam memutus perkara, karena disinilah letak peran Hakim Agung untuk melakukan penafsiran dalam menghadapi kasus konkrit. Oleh karena bagaimanapun Mahkamah Agung adalah instansi terakhir dari sebuah struktur pengadilan, yang diharapkan akan lebih mampu memberikan rasa keadilan dan kemanfaatan serta jaminan kepastian hukum itu sendiri.

3. Meskipun ada kebebasan hakim dalam menjalankan/melaksanakan putusannya maka hakim tidak harus legalistik tetapi mengadili menurut hukum dalam arti yang luas termasuk aktualisasi pengertian- 
pengertian yang sudah mapan, sehingga putusannya dapat mencerminkan rasa keadilan (dalam) masyarakat. Kewajiban Hakim adalah menerapkan hukum secara tepat dan benar demi mewujudkan keadilan atau memberi kepuasan pada pencari keadilan.

\section{F. Daftar Pustaka}

\section{Buku-buku:}

Adi Sulistiyono. 2006. Kekuasaan Negara Hukum, Dan Paradigma Moral. Surakarta: Sebelas Maret University Press.

Ahmad Kamil. 2012. Filsafat Kebebasan Hakim. Jakarta: Kencana Prenadia Media Group.

Ahmad Mujahidin. 2007. Peradilan Satu Atap Di Indonesia. Bandung: Refika Aditama.

Ahmad Rifai. 2010. Penemuan Hukum oleh Hakim Dalam Persfektif Hukum Progresif. Jakarta: Sinar Grafika.

Andi Hamzah. 2008. Hukum Acara Pidana. Jakarta: Sinar Grafika.

Anton Freddy Susanto. 2005. Semiotika Hukum : Dari Dekonstruksi Teks Menuju Progresivitas Makna. Bandung: PT. Refika Aditama.

Bambang Sunggono. 2005. Metodologi Penelitian Hukum. Jakarta: Rajagrafindo Persada.

Charles Himawan. 2006. Hukum Sebagai Panglima. Jakarta: Buku Kompas.

Esmi Warassih. 2005. Pranata Hukum Sebuah Telaah Sosiologis. Semarang: PT. Suryandaru Utama.
Evi Hartanti. 2014. Tindak Pidana Korupsi. Jakarta: Sinar Grafika.

Frans Magnis Suseno. 1995. Etika Politik. Jakarta: Gramedia.

H.B. Soetopo. 1992. Metode Penelitian Hukum. Jakarta: PT Gramedia Pustaka Utama.

Lilik Mulyadi. 2007. Hukum Acara Pidana: Normatif, Teoretis, Praktik dan Permasalahannya. Bandung: Alumni.

Mardjono Reksodiputro. 2009. Menyelaraskan Pembaruan Hukum. JakartaL KHN-RI. 2007. Sistem Peradilan Pidana Indonesia (Peran Penegak Hukum Melawan Kejahatan); Hak Asasi Manusia dalam Sistem Peradilan Pidana. Jakarta: Pusat Pelayanan Keadilan dan Pengabdian Hukum Universitas Indonesia.

Muladi dan Barda Nawawi Arif. 1998. TeoriTeori dan Kebijakan Pidana. Cetakan Kedua. Bandung: Alumni.

Padmo Wahyono. 1986. Indonesia Negara Berdasarkan Atas Hukum. Cet. Kedua. Jakarta: Ghalia Indonesia.

Paulus Efendi Lotulung. 2003. Kebebasan Hakim dalam Sistem Penegakan Hukum. Makalah. Seminar Pengembangan Hukum Nasional VIII. BPHN dan Dep. Kehakiman dan HAM RI. Denpasar. 14 - 18 Juli 2003.

Purwoto S. Gandasubrata. 1998. Renungan Hukum. Jakarta: IKAHI Cabang MARI.

Romli Atmasasmita. 2001. Reformasi Hukum, Hak Asasi Manusia \& Penegakkan Hukum. Bandung: Mandar Maju.

Satjipto Rahardjo. 2000. Ilmu Hukum. Bandung: PT Citra Adytia Bakti. 
. tanpa tahun. Masalah Penegakkan Hukum Suatu Tinjauan Sosiologis. Bandung: Sinar Baru.

Soejono Dirdjosisworo. 1984. Pengantar Ilmu Hukum. Jakarta: CV Rajawali.

Sudikno Mertokusumo. 2008. Mengenal Hukum. Suatu Pengantar. Yogyakarta: Liberty.

. 2003. Mengenal Hukum: Suatu Pengantar. Cetakan Pertama. Yogyakarta: Liberty.

Tama S. Langkun dkk. 2014. Studi atas Disparitas Pemidanaan Perkara Tindak Pidana Korupsi. Jakarta: Indonesia Corruption Watch.

Tina Asmarawati. 2015. Pidana dan Pemidanaan dalam Sistem Hukum di Indonesia (Hukum Penitensier). Yogyakarta: Deepublish.

Yahya Harahap. 2008. Kekuasaan Mahkamah Agung Pemeriksaan Kasasi dan Peninjauan Kembali Perkara Perdata. Jakarta: Sinar Grafika.

\section{Majalah dan Jurnal:}

Adrian IACOB, "Peculiarities of Criminal Investigations in Cases of Forgery and Use of Forgery", Article International Journal of Criminal Investigation, Volume 1, Issue 3, http://www.ijci.eu/ published/IJCI_16_Iacob.pdf.

P. Wignyosumarto. 2006. "Peran dan Tugas Hakim Pengawas". Varia Peradilan Nomor. 246 Tahun XXI.

Sanjay G. Reddy, 2012, "Public Policy Analysis Today and Tomorrow", Jindal Journal of Public Policy, Volume 1 Issue 1, August 2012, https://static. squarespace.com/static/51b8d8a3e4b0 12fbeaff36db/53066dfee4b043fee9afb 6ba/53066dfee4b043fee9afb6bd/1345 937709003/65publicpolicy.pdf.

S. B. M. Marume, 2016, "Public Policy and Factors Influencing Public Policy", International Journal of Engineering Science Invention, Volume 5 Issue 6, June 2016, ISSN (Online): 2319-6734, ISSN (Print): 2319-6726, http://www. ijesi.org/papers/Vol(5)6/B05060614. pdf.

Wan Abdul Fattah Wan Ismail, 2015, "Forms of Document Falsification in Malaysia's Syariah Court", Malaysian Journal of Society and Space, Vol. 11 issue 9, http://www.ukm.my/geografia/images/ upload/4x.fullgeo-sept15-wanfattahedam.pdf.

Yustina Trihoni Nalesti Dewi, W. Riawan Tjandra, and Grant R. Niemann, 2016, "Independence of Judicial Power as a Foundation of Human Rights Judicial Function in Indonesia", International Journal of Social Science and Humanity, Vol. 6, No. 3, March 2016, http://www. ijssh.org/vol6/650-H016.pdf.

\section{Peraturan Perundang-undangan:}

Undang-Undang Dasar Negara Republik Indonesia Tahun 1945 (UUD 1945).

Kitab Undang-Undang Hukum Pidana (KUHP).

Undang-Undang Nomor 8 Tahun 1981 Tentang Kitab Undang-Undang Hukum Acara Pidana (KUHAP).

Undang-Undang Nomor 48 Tahun 2009 tentang Kekuasaan Kehakiman.

Undang-Undang Nomor 30 Tahun 2004 tentang Jabatan Notaris. 